\title{
The Effectiveness of Content Mastery Services with Internet - Based Problem Based Learning Models in Enhancing Student Critical Thinking Skills
}

\author{
Amrina Asfarina ${ }^{1}$, Marjohan ${ }^{1}$, Riska Ahmad ${ }^{1}$ \\ ${ }^{1}$ Universitas Negeri Padang \\ *Corresponding author, e-mail: amrinaasfarina@gmail.com
}

\begin{abstract}
The development of information and communication technology has a gross impact on all aspects of life, including education. Therefore it provides convenience and flexibility in exploring science. However, information in Internet is not always verified. Therefore critical thinking is highly needed in dealing with these developments. The objective of this research was to determine the improvement of students' critical thinking skills after participating in content mastery services with Internet-based problem learning models. This study is a Quasi-Experiment which uses quantitative methods and The Non-Equivalent Control Group Design. The subjects of this study were students of Public High School 2 in Padang. Furthermore, the research instrument used was a Likert model scale. Data analysis was performed with the aid of the Wilcoxon Signed Ranks Test and the KolmogorovSmirnov Two Independent Sample test. According to the research, content mastery services with Internet-based problem learning models are effective for improving students' critical thinking skills.
\end{abstract}

Keywords: Critical Thinking Skills, Content Mastery Services, Internet-Based Problem Based Learning

How to Cite: Asfarina, A., Marjohan, M., \& Ahmad, R. (2018). The Effectiveness of Content Mastery Services with Internet-Based Problem Based Learning Models in Enhancing Student Critical Thinking Skills. International Journal of Research in Counseling and Education 3(1), 55 - 58, https://doi.org/10.24036/0094za0002

\section{Introduction}

Changes in learning behavior can be seen in various manifestations, and one of thisis a critical thinking. Fisher (2008) defines it as an evaluative process that includes both criticism and creativity. Moreover, it deals with the quality of thoughts or arguments presented to support a belief or series of actions. Furthermore, critical thinking skills according to Angelo (1995) are: (1) analyzing abilities, (2) synthesizing potencies, (3) skills in identifying and solving problems, (4) concluding skills, and (5) evaluating or judging skills. During this process, students need to master the above competencies to be able to assess an idea or information without increasing or reducing the thoughts presented according to specific criteria.

The development of the world is tied to knowledge sources, specifically the internet. It is one source of learning that has continuously developed over the years(Calhoun, 1999). Its role in global development is increasing daily. The results of the research by Marnita, Ahmad, \& Said (2014) shows that $49.28 \%$ of students use the internet for sourcing information. Furthermore, Nasution, Neviyarni, \& Alizamar (2017) stated that high school students use smartphones connected to the web to find relevant information related to lessons.

Critical thinking can be enhanced by Guidance and Counseling teachers with various services, such as content mastery services. According to Prayitno (2012), content mastery service allows students to understand and develop good learning attitudes, habits, skills and material that are required to solve learning problems.

Method

This study is a Quasi-Experiment which used the quantitative methods and The Non-Equivalent Control Group Design. The subjects were 30 students of Public High School 2 in Padang. The research instrument used 
was a questionnaire of students' critical thinking skills with a Likert model scale. The validity test of the instrument was conducted using the Pearson Product Moment correlation formula, and the instrument reliability test was performed using the Cronbach Alpha technique with the aid of the SPSS version 2.0 program. Data analysis was conducted with the Wilcoxon Signed Ranks Test and the Kolmogorov-Smirnov Two Independent Sample test.

\section{Results and Discussion}

\section{Research result}

\section{Results of Experimental Data Critical Thinking Skills}

The experimental group students experienced an increase in critical thinking skills after content mastery services was provided with an internet-based problem learning model. Before this service was given, the pretest average score was 129.5 and it attained the medium category. After the content mastery services was provided with the model, the average score of posttest increased to 179.97 and was in the high category.

\section{Data Results of Control Group Student Critical Thinking Skills}

Critical thinking skills of control group students increased after the content mastery services were given. Before, the pretest score was 129.27 and it was in the medium category. Furthermore, after the content mastery service was provided with the discussion method, the posttest average score is 165.77 and has increased into the high category. The results of the increase that occurred in the control group were lower than the experimental group and had an average difference of 14.2 .

\section{Hypothesis testing}

Proper examination with the Kolmogorov Smirnov 2 Independent Samples test on the experimental and the control group showed that the results of the probability of Asymp. Sig. (2-tailed) Critical thinking skills of the experimental group and the control group were 0.035 , or the probability was below $0.05(0.035$ $<0.05$ ). Therefore, there is a significant difference in the critical thinking abilities of the experimental group students and the control group.

\section{Discussion}

The data show significant differences in the critical thinking abilities of the experimental and control group students. A discussion was conducted to understand the result of the research.

\section{Student Critical Thinking Skills}

The results indicated that the average pretest score of critical thinking skills in each group was in the same category. The average rating of the thinking ability of the experimental group is 129.5, and for the control group is 129.27. Furthermore, from the analysis conducted using the Kolmogorov Smirnov, 2 Independent Samples test was obtained by Asymp. Sig. (2-tailed) Of 0.968 or probability above 0.05 . The results showed that the experimental and the control groups did not have significant differences in the same category.

The improvement of the students' critical thinking can be enhanced by the effort of the Counselor (BK teacher) through the content mastery service. Cottrell (2005) explained it as a cognitive activity, related to the use of the mind and it involves several mental processes, such as attention, categorization, selection, and judgment. In the experimental group, the treatment given was content mastery service with an internetbased problem learning model. In the control group, content control services, was implemented with discussion methods. After each group was given treatment, the students' critical thinking skills improved. The posttest results of the experimental group and the control group had an average scores 179.97 and 165.77 respectively for critical thinking ability. According to the calculations, each group fell into high category.

Therefore, it can be concluded that the increase that occurred in the critical thinking skills of the experimental group was 50.47 while the control group had only 36.5 . Hence it can be concluded that there was an increase in both experimental groups. 
2. Differences in the Critical Thinking Skills of Students in Experimental Groups (Pretest and Posttest)

This service tends to increase the rate of change in students' critical thinking skills significantly. This can be seen from the results of the average score of the experimental group before being treated as 129.5 with the moderate category, and then after being given a treatment of 179.97 with a high category, the increase occurred at 50.47. Also, the process of mastering content services with Internet-based problem based learning models makes students active and responsive to the learning process. During the service activities, the recipients are divided into several groups. They actively convey the results of group problem solving and were also able to proffer solutions to the purpose of the learning process.

One way to improve students' critical thinking skills is by providing content mastery services. According to Ahmad (2013), it helps to save students from various problems that arise from the inability to understand mastery. It will help develop their abilities better. The problem-based learning model is built to solve the situation. Sudarman (2007) reported it uses real-world challenges to teach the students and help them acquire knowledge of the subject matter.

Furthermore, Trianto (2010) reported that the problem-based learning model has to do with issues that require factual inquiries such as investigations. Riyanto (2009) reported that it helps students to be active and independent in developing thinking skills for solving problems through searching for data to obtain solutions. According to the research, content mastery services with Internet-based problem learning models needs to be implemented. It will help the students gain knowledge of the internet to solve problems during group discussions (Ardi, Viola, \& Sukmawati, 2018). The use of the web enhances students' activeness and alertness during discussions.

\section{Differences in Students' Critical Thinking Skills in the Control Group (Pretest and Posttest)}

From the results, there were slight differences in the score of critical thinking skills of the control group students before and after treatment. The average rating of students' thinking ability before treatment is 129.27, therefore, it is ranked in the medium category. Furthermore, after the treatment with the discussion method, the average score was 165.77, it now ranked in the high category. The increase in the average score of the control group before and after being given treatment is 36.5 . This is because during content mastery service, students only responded to each other's answers while class discussions and explanation of materials was delivered in their local language. An increase occurred because students got a new understanding of the material discussed.

Content mastery services were conducted to improve the critical thinking ability of control group students when researchers provide material, students pay attention to the explanation, and occasionally the researcher gives questions and then ask for student responses. The students respond to each other with their answers in the form of class discussions. They are later asked to explain the material in their language again. The aim of this practice is to see if the students properly understood the material. According to the pretest and posttest result, the control group experienced less increase compared to the experimental group because the content mastery service was given to the control group using the discussion method

\section{Differences in Students' Critical Thinking Skills in Experimental Groups and Control Groups}

There is a slight difference between the experimental and the control groups because of the various models used. This is seen from the results of the experimental group posttest average of 179.97 and the control group at 165.77. According to the results, the 2 groups had a difference of 14.2. The hypothesis test was conducted to prove that the value of Asymp. Sig. (2-tailed) Critical thinking skills of the experimental group and the control group were 0.035 , and the probability was below $0.05(0.035<0.05)$. Thus it can be concluded that there is a significant difference in the critical thinking skills of the experimental and the control group. The two research groups were given the same service, but the experimental group used an Internet-based problem learning model and the control group used the discussion method.

Cottrell (2005) suggests six benefits of critical thinking, and they include:

1. Increasing attention and observation

2. Focusing more on reading

3.Increasing the ability to identify essential points of a text or other information beyond less important learning material 
4. Improving the ability to respond to points that are appropriate in information

5. Knowledge of how to get personal opinions easily

6. Analytical skills that can be chosen to be applied in various situations. This is beneficial for students facing the development of information and communication, especially in learning.

According to the results of data analysis, it can be concluded that content mastery services and the Internetbased problem learning modelsmodels are more effective in improving students' critical thinking skills. This effectiveness can be seen from the total number of analysis conducted where the scores of the experimental group experienced a higher increase than the control group.

\section{Conclusion}

From this research, the internet-based learning model is more effective in improving students' critical thinking skills than discussion methods. The summary of this research can be concluded as follow:

1. There are significant differences in the critical thinking skills of the experimental group students before and after participating in content mastery services

2. There is a significant difference in the critical thinking skills of the control group students before and after participating in content mastery service

3. There is a significant differences in the critical thinking skills of the experimental group students who were given content mastery services with an internet-based problem-based learning model and the control group students mastering content with the discussion method.

In categorizing critical thinking skills, both groups attained high category, but the average increase is greater in the experimental group. Content mastery services have been tested for effectiveness in this study.The research focuses on encouraging students improve their critical thinking skills about internet usage, and also perform analysis, synthesis, recognize and solve problems, conclude, and evaluate all information sourced from the Internet.

\section{References}

Ahmad, R. (2013). Dasar-dasar Bimbingan dan Konseling. Padang: UNP Press.

Angelo, T. A. (1995). Classroom Assessment for Critical Thinking. Teaching of Psychology, 22(1), 6-7.

Ardi, Z., Viola, K., \& Sukmawati, I. (2018). An Analysis of Internet Abuses Impact on Children s Moral Development. JPPI (Jurnal Penelitian Pendidikan Indonesia), 4(1), 44 50. Retrieved from http://jurnal.iicet.org/index.php/jppi/article/view/192

Calhoun, T. (1999). Internet Teaching and Learning Resources from Indiana University and the University source of New Brunswick. Retrieved from http://technologysource.org/article

Cottrell, S. (2005). Critical Thinking Skills: Developing effective analysis and argument. New York: Palgrave Macmillan.

Fisher, A. (2008). Berpikir Kritis: Sebuah pengantar: Jakarta: Erlangga.

Marnita, W., Ahmad, R., \& Said, A. (2014). Komunikasi Interpersonal Siswa Pengguna Internet dan Implikasinya terhadap Layanan Bimbingan dan Konseling. Jurnal Konseling Dan Pendidikan, 2(1), 8-14.

Nasution, J. A., Neviyarni, S., \& Alizamar. (2017). Motif Siswa memiliki Smartphone dan Penggunaannya. Jurnal Penelitian Pendidikan Indonesia, 3(2), 15-29.

Prayitno. (2012). Jenis Layanan dan Kegiatan Pendukung Konseling. Padang: UNP Press.

Riyanto, Y. (2009). Paradigma Baru Pembelajaran. Jakarta: Kencana Prenada.

Sudarman. (2007). Problem Based Learning: Suatu model pembelajaran untuk mengembangkan dan meningkatkan kemampuan memecahkan masalah. Jurnal Pendidikan Inovatif, 2(2), 68-73.

Trianto. (2010). Model Pembelajaran Terpadu. Jakarta: Bumi Aksara. 
